\title{
Conquering Constraints and Expanding Ethos: FDR's 1932 Commonwealth Club Address
}

\author{
Tammy R. Vigil \\ Correspondence: Tammy R. Vigil, College of Communication, Boston University, 640 Commonwealth Ave., Boston, \\ MA, 02215, USA
}

Received: April 11, 2015 Accepted: April 29, 2015 Online Published: May 4, 2015

doi:10.11114/smc.v3i1.760

URL: http://dx.doi.org/10.11114/smc.v3i1.760

\begin{abstract}
FDR's Commonwealth Club Address is a well-regarded speech that suffers from a lack of critical attention by rhetorical scholars. This essay compliments previous contextual and ideological critiques of the speech by examining the rhetorical strategies Roosevelt used to enhance his ethos and overcome key constraints encountered in the summer of 1932. Hampered by the rules of the Commonwealth Club (rules requiring non-partisan speeches), the complexity of the audience and the details of his own life, Roosevelt conquered these constraints by adroitly employing strategies of ingratiation building and personae adoption. Additionally, FDR built and maintained a rhetorically consistent oeuvre that enhanced his credibility by demonstrating his reliability, stability and trustworthiness.
\end{abstract}

Keywords: Franklin Roosevelt, presidential campaign rhetoric, ethos

\section{Introduction}

Over three-quarters of a century ago, as part of his first campaign for the presidency, Franklin Delano Roosevelt delivered a speech now commonly referred to as the Commonwealth Club Address. During the several decades following the September 23, 1932 oration, the address has been evaluated in a variety of ways. Media assessments of the speech at the time of its utterance were largely unfavorable (Boettinger, 1932; "Roosevelt Airs Business Views," 1932). Later critiques recognized it as a "historically significant" policy statement previewing the much-debated "New Deal" ("For Dynamic America" 1940; Horgan, 2007; Milkis, 1985). A poll of rhetorical scholars almost seven decades after its delivery listed the speech among the 100 most influential addresses of the $20^{\text {th }}$ century ("American Rhetoric," 2007; Lu \& Sullivan, 2004; Lucas and Medhurst, 2008). For an assortment of reasons, it has been deemed an important speech.

In a 2004 Rhetoric \& Public Affairs article, Davis Houck questioned the greatness of FDR's Commonwealth Club Address. Based largely on questions of authorship, ideology and inconsistency of message, Houck declares, "it is not a great speech" (2004, p. 275). He cites several reasons for this assessment:

...the speech is devoid of eloquence or sublimity of expression; the speech is certainly not prophetic even though some discern a philosophical underpinning to the New Deal; there is nothing transcendent or even memorable in the address, save perhaps the allusion to the frontier thesis; the mature economy thesis is a feeble attempt to warrant, however tentatively, a new relationship between government and business; the speech is clearly reflective of Adolph and Beatrice Berle's beliefs far more than the speaker as he delivered it on September 23, 1932; the link between the closing of the western frontier and economic stagnation is a quaint misappropriation of Fredrick Jackson Turner's influential thesis; the new individualism turns out to be nothing new at all, at least in the government's responsibility to protect property rights; the address does not presage Roosevelt's philosophy of governance, whose preferred method, if ever there was one, was articulated earlier in the campaign as "bold, persistent experimentation"; the immediate audience was clearly not moved by the address; and the moods of the address fluctuate between blissful optimism and bureaucratic gloom. (Houck, 2004, p. 275-6)

Questioning the value of the speech, Houck criticizes colleagues, arguing, "...public address scholars...blithely ignore any discrepancies - of ideology or authorship" (p. 277) resulting in the speech being "adjudicated by reputation alone" (p. 276).

Houck's assessment of FDR's Commonwealth Club Address is interesting, if not vexing, for scholars. He provides a wealth of contextual information about the speech and calls attention to a true "critical void" in rhetorical criticism 
surrounding the address (Note 1). Houck's critique correctly illustrates the need for further analysis of the speech. Because his overall assessment focuses primarily on authorship and ideological issues, it leaves space for a more traditional rhetorical analysis focusing on content, structure and method. In the years since Houck's critique was published, little has been done to fill the gap in scholarship surrounding this address; we still lack an effective analysis of the rhetorical techniques present throughout the speech. This essay helps fill that void.

Rather than replicate Houck's ideological assessment of the address and previous attempts to tie the speech to the larger political framework of FDR's administration, this analysis examines the internal elements of the speech and its connection to Roosevelt's other 1932 campaign orations. This emphasis on content results in a rhetorically focused analysis of the Commonwealth Club Address that compliments Houck's ideologically-based assessment by filling in a different portion of the scholarly lacuna surrounding this speech. Of particular interest are the ethos-building strategies Roosevelt uses to combat the constraints faced. This essay examines his attempts at ingratiation, his persona adoption, and his rhetorical consistency.

\section{Review of Relevant Literature}

\subsection{Historical Context}

The 1932 presidential candidates faced a barrage of difficulties. The Great War was followed by an historic international economic collapse. Amidst the Great Depression, citizens faced an uncertain future. While many Americans embraced an insular or isolationist approach to international affairs, the economic collapse of 1929 demonstrated the interdependence of international interests (Burns, 2002). Facing an economically and emotionally depressed electorate, a world reeling from war and poverty, and a heated debate over the need for decisive government action, the candidates of 1932 encountered unprecedented challenges (Gosnell, 1952).

Franklin Delano Roosevelt, then governor of New York and presidential candidate, won a hard-fought primary battle for the Democratic presidential nomination (Leuchtenburg, 2009). Contending with former ally turned critical opponent $\mathrm{Al}$ Smith and others, FDR won the nomination on the $4^{\text {th }}$ balloting. In a "back room" compromise, he offered the vice-presidential spot on the Democratic ticket to John Nance Garner in exchange for the necessary delegate votes (Fried, 1999).

FDR began his "official" campaign for the White House in a unique manner. By accepting the nomination during a public address at the Democratic National Convention, FDR began the tradition of the "on-site" nomination acceptance address. Rather than adhering to the traditional ritual whereby delegates and friends "informed" the candidate of his selection a week or two after the convention, FDR held the delegates late at the convention so he could accept the nomination in person at the time of his selection (Burns, 2002). Doing so, FDR laid the groundwork for many common themes of his candidacy and presidency. He explains his break with tradition as "the symbol of my intention to be honest and to avoid all hypocrisy or sham, to avoid all silly shutting of the eyes to the truth of this campaign" (Roosevelt, 1938, p. 647). Roosevelt set the stage for a campaign and presidency that embraced oratory as a significant means of influence.

By September 1932, Roosevelt was struggling through a series of campaign stops throughout the Midwest and West (Ritchie, 2007). While Roosevelt's "major issue" speeches at designated locations (i.e. farm policy in Topeka, Kansas; railroads in Salt Lake City, Utah; tariffs in Seattle, Washington) were not particularly well received, his minor "whistle-stop"-type speeches were frequently a big hit. Roosevelt's talk at the Commonwealth Club was originally intended to be an impromptu, community-based speech of little importance (Houck, 2004, p. 266). However, after considering the nature of the audience, FDR decided he would give an address that, some say, laid the foundation for his economic stimulus plan, the "New Deal" (Leuchtenburg, 2009).

\subsection{Constraints}

FDR faced many constraints when addressing the Commonwealth Club of California in 1932. They divide into three related categories: restrictions enforced by the venue, the complexity of the audience, and the candidate's patrician past.

Founded in 1903, the Commonwealth Club mission has been "to be the leading national forum...for the impartial discussion of public issues important to the membership, community and nation" ("Commonwealthclub.com," 2007). The expectation of speakers at the Commonwealth Club has always been a bipartisan or non-partisan approach to the topic at hand. However, speeches given by candidates in the context of a presidential campaign are, by their very nature, intended to be persuasive (Campbell \& Burkholder, 1997; Denton \& Woodward, 1998). No matter the rules of the sponsoring organization, a candidate's orations cannot be separated from the larger context of the campaign and the candidate cannot be detached from the pursuit of the desired position. As a candidate seeking to unseat an incumbent president, Roosevelt had decidedly partisan goals and he needed the support of the well-educated and influential audience of western businessmen. Addressing the Commonwealth Club, FDR had to balance his desire to campaign 
actively and forward his agenda with the need to respect the club's policy requiring nonpartisan discussion of public affairs. A quick speech lacking substance and showing a great deal of personality would have been the safest approach to the situation. However, as with many of his campaign decisions, FDR opted for a risky route rather than a safe one (Gosnell, 1952; Burns, 2002; Ritchie, 2007).

Roosevelt's plan required businesspeople to participate in the "new economic social order"; he needed the support of the Commonwealth Club members and others like them for his plan to work. This brings to the forefront the second constraint for the speech: the complex audience. The immediate audience for the September $23^{\text {rd }}$ speech was the San Franciscan club. This group of western businessmen had a vested interest in the economic health of the nation. As a group subscribing to the "self-made man" mythos of the West, the group likely leaned toward a small-government/minimal-intrusion philosophy. Roosevelt faced the challenge of convincing these individuals to support greater government intervention and more self-regulation in business.

The second level of audience for the Commonwealth Club Address made the rhetorical situation FDR faced even more challenging. Savvy about the influence of mass media, FDR knew each address had the potential to reach well beyond the immediate audience. The distribution of texts and reports of the speech meant the situation called for a well-crafted message that avoided alienating his established base while courting the immediate audience. FDR had been enormously popular with "plain folk," farmers, and those living in small towns and rural areas, but he needed to build a larger support base among businesspeople, intellectuals and urban voters (Fried, 1999). Roosevelt could not simply pander to intellectual and economic elites, nor could he risk contradicting his previous statements. Like modern candidates, FDR had to maintain consistency of message and develop substantive points while appealing to multiple audiences.

In addition to managing the restrictions of the venue and the complexities of a multifarious audience, FDR faced a third related constraint: his own history. A patrician by birth, the socially "elite" status associated with an east coast governor born to a life of privilege ran counter to the "self-made man" image with which most westerners, particularly western elites, identified (Burns, 2002). Many members of the immediate audience prided themselves on the struggles they endured to reach the positions of power and prestige they enjoyed. Roosevelt had to connect with this audience and win it over. His success currying support of "plain folk" demonstrated his ability to transcend the divisions of class (Gosnell, 1952), but this distinct type of voter posed a new challenge.

Although Roosevelt relied on speechwriters to author several of his campaign addresses, including the Commonwealth Club Address (Burns, 2002; Houck, 2004; Leuchtenburg, 2009), FDR assumed ownership of the speech through the act of delivery. As is standard practice, this analysis treats the text as though it is entirely his. Therefore, the Commonwealth Club Address illustrates FDR's awareness of the constraints he faced in giving the speech and his adroit use of rhetorical strategies to overcome them.

\section{Results of Analysis}

FDR's Commonwealth Club Address is an object lesson in overcoming rhetorical constraints. While the speech did not mark a "make or break" moment in the campaign or Roosevelt's political career, it does illustrate his oratorical skills and ability to adapt to multiple potentially unreceptive audiences with grace and efficacy. The rhetorical strategies Roosevelt employs throughout the oration demonstrate successful development of ethos and illustrate its importance in skillful campaigning.

In the article "Lincoln at Cooper Union," Leff and Mohrmann argue, "the ultimate goal of the campaign orator is to promote himself as a candidate. Both policies and character are in question, but the treatment of issues is subsidiary to the purpose of creating a general identification between the speaker and the audience" $(1995$, p. 176). This development of identification is a means of persuading the audience of the candidate's credibility by creating a connection between candidate and audience that potentially translates into votes in his or her favor and support for the candidate's ideas and proposals (Denton \& Woodward, 1998; Note 2).

Because even the most bipartisan campaign addresses function as acts of persuasion through identification building, the need to enhance an audience's perception of the speaker has always been an essential component of public speeches. Aristotle explains, "The character of the speaker is a cause of persuasion when the speech is uttered as to make him worthy of belief; for as a rule we trust men of probity more, and more quickly, about things in general, while on points outside the realm of exact knowledge, where opinion is divided, we trust them absolutely" (trans. 1932, p. 8). He continues, "in conducing to persuasion it is highly important that the speaker should evince a certain character, and that the judges [audience] should conceive him to be disposed towards them in a certain way, and further, if possible, that the judges [audience] themselves should have a certain attitude toward him" (p. 45). As a general rule, "we are persuaded when we think the speaker to be a man of a certain character - that is, when he seems to be good, or well-disposed or both" (Aristotle, trans. 1932, p. 45). For this reason Aristotle argues that "character [ethos] is the most potent of all means to persuasion" (p. 9). Strategies for evincing positive ethos are always of interest, particularly 
strategies for enhancing the three components that activate our trust in a speaker, namely intelligence, character and good will (p. 91). In the Commonwealth Club Address, FDR illustrates the importance of ethos and effective ways of developing, and maintaining it through ingratiation, persona adaptation, and rhetorical consistency.

\subsection{Ingratiation}

Given the numerous attempts at ingratiation throughout the Commonwealth Club Address, FDR understood that "trust...should [also] be created by the speech itself and not [solely] left to depend on an antecedent impression" (Aristotle, trans. 1932, p. 9)

As commonly occurs in most speeches (Carey, 1996), the prooemium of the Commonwealth Club Address contains a great deal of ingratiation building. Roosevelt opens the oration by thanking the audience for the invitation to speak. He begins, "I count it a privilege to be invited to address the Commonwealth Club. It has stood in the life of this city and state, and it is perhaps accurate to add, this nation, as a group of citizen leaders interested in fundamental problems of government, and chiefly concerned with the achievement of progress in government through non-partisan means" (Roosevelt, 1932, II 1). Failure to recognize the audience in such an address would be jarring and awkward, so Roosevelt uses this opening to meet the initial expectations of the audience and to "get his audience into the right state of mind" (Aristotle, trans. 1932, p. 91). With such a start, Roosevelt attempts to gain respect from the audience by showing respect for the audience. Although the actual phrasing is neutral, the way the opening is framed seems complimentary. Roosevelt emphasizes his intent to respect the organization and its members by following its "non-partisan" policy. Here he effectively demonstrates a classic means of inducing liking for "we like those who take us seriously - who admire us, who show us respect, who take pleasure in our society" (Aristotle, trans. 1932, p. 105). This initial attempt at ingratiation serves a dual function for the would-be president. By acknowledging the Commonwealth Club as "a group of citizen leaders" and delineating their concerns, FDR clearly shows regard for those present. More importantly, he subtly reminds listeners of their professed open-mindedness in the assessment of ideas, thus encouraging their receptivity.

It is important to note that FDR's phrasing in this opening primes the audience for arguments to come. Rather than using terms like "politics" and "parties" he frames the discussion as regarding "government," "achievement" and "progress"-issues of interest for Roosevelt and the audience. The second paragraph of Roosevelt's opening makes this connection explicit. He explains, "I want to speak not of politics but of government. I want to speak not of parties, but of universal principles" (Roosevelt, 1957, p. 74). The use of parallelism and antithesis makes the line rhetorically interesting and memorable. It also reinforces a commonality with the audience, reiterates his intent to follow club rules and implies the speech has importance beyond the particular event. It is also a first glimpse at Roosevelt's use of transcendent terms to evoke a sense of commonality beyond the immediate audience and situation.

The development of ethos through ingratiation continues throughout the introduction of the speech. Acknowledging the context in which they are living ("Sometimes...particularly in years such as these, the hand of discouragement falls upon us" 4), Roosevelt points to the audience as part of the hope for the future. He argues, "America is new. It is in the process of change and development. It has the great potentialities of youth, and particularly this is true of the great West, and of this coast, and of California" ( $(5)$. While this may sound like pandering, it is really priming the audience for a later invitation to participate in the revitalization of the country. This empowering statement also creates a sense of strength beyond the particular members of the club. The line does not limit the "great potentialities of youth" to the club members, but includes people throughout the region. Here Roosevelt includes the larger secondary audience, extending the ingratiation efforts beyond the Commonwealth Club.

The final paragraph of FDR's introduction contains an additional attempt to curry the audience's favor. He compliments the audience, saying, "I appreciate that the membership of this club consists of men who are thinking in terms beyond the immediate present, beyond their own immediate tasks, beyond their own individual interest. I want to invite you, therefore, to consider with me in the large, some of the relationships of government and economic life that go deep into our daily lives, our happiness, our future and our security" ( $\$ 7$ ). This is an important transition toward the body of the speech. By casting the audience in idealistic and transcendent terms, Roosevelt makes it difficult for members to refuse participation in the new economic social order he proposes. To do so, they would have to admit having limited interests and reveal their selfishness. Also, the repeated use of the collective, possessive pronoun "our" further conjoins the concerns of the speaker and his audience. Later, the "our" incorporates broader society, too.

FDR further attempts to induce good will from the audience by making positive assumptions about audience members through the labels he uses when referring to them. He carefully distinguishes between the audience of "enlightened businessmen" who form a necessary and integral part of his progressive new plan and the "princes of property" who hinder effective economic and governmental progress. He points to "enlightened industries" that "endeavor to limit the freedom of action of each man and business group within the industry in the common interest of all" ( $\mid 29$ ) as evidence 
of the soundness of his call for governmental assistance regulating industry. By labeling self-regulating industries and supportive businessmen as "enlightened," Roosevelt shows positive regard for progressive businesspeople that accept some government intervention. Furthermore, Roosevelt encourages the support of these businessmen by claiming the support of other successful men elsewhere. He explains, "The men who have reached the summit of American business life know this best; happily many of these urge the binding quality of this greater social contract" ( $\$ 33$ ). FDR encourages audience members to identify with the "enlightened" and successful businessmen by addressing them as though they already fall into this category.

Roosevelt continues to ingratiate himself with the audience in the conclusion of the Commonwealth Club Address. He begins the final paragraph with appeals to the common beliefs of most members of his extended audience. He asserts, "Faith in America, faith in our tradition of personal responsibility, faith in our institutions, faith in ourselves demands that we recognize the new terms of the old social contract. We shall fulfill them as we fulfilled the obligation of the apparent utopia which Jefferson imagined for us in 1776" ( $\$$ 43). This appeal rhetorically creates a bond among audience members while making their support historically significant. Audience members would be hard-pressed to deny their own faith in the entities listed, particularly in light of the pervasive "self-made man" mythology of the U.S. and the American West.

There is ample evidence of Roosevelt's rhetorical connection building with his audience and his various attempts at ingratiation. While most examples here concern the immediate audience of the Commonwealth Club, there are additional examples to illustrate continued ingratiation with the extended audience. His focus on "every man" rather than exclusively kowtowing to the business elite is one way in which FDR ingratiates himself with the larger audience. By providing examples of the importance of a redistribution of wealth and focusing on the need to protect the rights of the mass of individuals, Roosevelt keeps his base support among "common" folks, farmers, and small businesspeople. In this case, direct attempts at ingratiation with this extended audience are not as essential as those with the immediate, and more likely unsympathetic, Commonwealth Club audience. However, even if not essential, they are present. This further illustrates FDR's understanding of the importance of actively maintaining credibility, not merely establishing it and assuming its continuance.

\subsection{Persona Adoption}

The body of the Commonwealth Club Address is divided into three parts: a history lesson, delineation of present problems, and a progressive plan for the future. In each section, Roosevelt adopts one of two complimentary personae to help him transcend the constraints of the situation and more effectively appeal to the audience.

In the first two sections of the oration, the history lesson and consideration of the present situation, Roosevelt assumes the role of an educator, informing the audience of key issues relevant to the topic at hand. Immediately following the introduction, Roosevelt embraces the role of educator by giving the audience a "history lesson" in the evolution of government and economics. This lesson sets the foundation for the argument to come. The body of the speech starts with a summary of centuries-long struggles to develop effective forms of government based on varying political philosophies. Roosevelt begins, "The issue of government has always been whether men and women will have to serve some system of government or economics, or whether a system of government and economics exists to serve individual men and women. This question has persistently dominated the discussions of government for many generations" ( $\$$ ). Here he clearly states the central theme of the speech, increasing the gravitas of the present discussion by placing it in a broad historical context. He also affords unsympathetic members of the audience comfort by conceding that the debate is long-standing and, as of yet, unresolved. This provides room for assessment and disagreement without creating permanent fissures between those with opposing viewpoints.

FDR's historical summary outlines the struggles faced as "people have worked to win the privilege of government" (ף 10), beginning with a general discussion of the evolution of national governments in Europe before moving to the development of American democracy. These difficulties, most of which appear cyclical, include debating the wisdom of a centralized government, balancing between increasing and restraining the power of ambitious individuals and discovering the appropriate relationship between the government and those governed-each a central concern in the 1932 campaign.

This history lesson enhances Roosevelt's overall credibility in a number of ways. The lesson increases FDR's perceived intelligence and integrity. It contextualizes the actual economic and political struggles of the day and delineates recurring changes in social circumstances as well as patterned responses to those changes. By focusing on the consistencies emerging from change, Roosevelt places the Depression in a larger socio-historical context providing insight into the cyclical nature of economic, social and political change and an optimistic outlook for the future. Doing so allows FDR to illustrate his intelligence, grasp of history and interest in the bigger, deeper questions related to governance, extending his interests beyond the simple assumption of power. 
The second way the educator persona enhances FDR's ethos deals with integrity. The history lesson addresses multiple perspectives in the development of government. Like a professor exploring an idea dispassionately, Roosevelt does not condemn the ambitious entrepreneur outright, but lauds the usefulness of such persons in a developing society while questioning the wisdom of allowing ambition to become unchecked power. Rather than rejecting his opposition outright, FDR acknowledges the validity of alternative perspectives. Discussing the Jefferson/Hamilton duel, Roosevelt acknowledges Hamilton, an opponent of FDR's idealized iconic leader, as a "brilliant, honest and able man" (ף 14) with reasonable perspectives. By demonstrating his understanding of opposing views, Roosevelt enhances his assumed persona as an educator and increases his perceived integrity by espousing a non-partisan, open-minded approach to important questions at hand. He reveals the intentionality of this persona adoption when he explains his understanding of the role of the statesman as necessarily that of a teacher. He argues, "the greatest duty of a statesman is to educate" (ף 42).

In proposing his progressive policy initiative, Roosevelt assumes the persona of the statesman. Throughout the Commonwealth Club Address he rhetorically moves beyond the realm of politics and political maneuvering. He offers himself as an ethical, honorable, and reliable guide during the trying times ahead. Not once in the entire address does he speak of politicians. Instead, he talks of "statesmen" and the tasks of "statesmanship." He speaks based on his "recollection of a long life spent for a large part in public office" and draws on his experience as the governor of New York. Mentioning these credentials and avoiding "politicking" enhances his role as a statesman.

Roosevelt's entire argument is framed as predicated upon a greater good, a greater meaning and more honorable intentions than those commonly associated with politicians. His care to highlight a "turning point" in governmental development as the "rise of the ethical conception that a ruler bore responsibility for the welfare of his subjects" ( 13 ) frames his regard for ethical, citizen-centered leadership. Calling on iconic documents like the Declaration of Independence and allusions to memories of the "founding fathers," FDR further invites the audience to view him as a man of integrity, capable of ethically leading the country through difficult times. Taking on the role of statesman encourages audience members to view him not as a politician seeking votes, but as an established leader concerned with the welfare of the people.

Roosevelt enhances his integrity and thereby builds his ethos by adopting the appropriate persona for the various portions of his address. The fact that the educator persona and statesman role are similar and feed into one another so easily creates a smooth transition between the two. Selecting divergent persona may have resulted in a jarring and distracting rhetorical schizophrenia. Here, FDR's display of rhetorical savvy enhances his credibility. However, Roosevelt's attempts to enhance his perceived integrity are not limited to persona development and ingratiation efforts. He also reassures his audience of his trustworthiness by demonstrating rhetorical consistency.

\subsection{Building Integrity through Consistency}

In his more ideologically focused assessment of the Commonwealth Club Address, Houck (2004) claims that the speech is a more accurate reflection of the speechwriters' ideology than that of FDR. While there may be a reflection of the Berles' political and economic perspectives in the address, a comparison of the content of this speech to other works in Roosevelt's oeuvre reveals substantial consistency in theme, philosophy, and rhetorical strategies employed.

The first and most obvious commonality across Roosevelt's speeches and essays is the prime place he gives history. His affinity for and knowledge of history provide a steadfast backdrop for his claims about government. In December 1925, Roosevelt wrote the essay "Is there a Jefferson on the Horizon?" Prompted by his reading of Bowers' book Jefferson and Hamilton, the essay outlines the historic battle of perspectives between Thomas Jefferson and Alexander Hamilton and argues that understanding history can create a more productive present and future. FDR argues of the book, "the chief revelation is not the day by day contest of the first ten years of the constitutional United States, but the constantly recurring thought of parallel or at least analogous situations existing in our own generations" (1957, p. 45). He continues, positing that the purpose of historical knowledge is to "apply the basic ideals of those days to the later events in American history and to the often essentially similar problems that still lie unsolved before us" (p. 45). A truncated version of this essay appears in the "history lesson" portion of the Commonwealth Club Address. This use of historical lessons as applicable to present situations is clear throughout the first third of the speech.

Throughout the 1932 campaign FDR began many of his addresses delineating ties to history. During an April 18, 1932 address at the Jefferson Day Dinner, Roosevelt repeatedly draws on historical figures such as Jefferson, Franklin, Jackson, Lincoln and others and alludes to the founding documents of the United States. FDR links his own ideas and actions to esteemed political leaders, particularly Thomas Jefferson. This is most obvious when Roosevelt, amidst his own cross-country campaign, refers to how Jefferson travelled "slowly and laboriously accumulating an understanding of the people of his country" (1932, "Jefferson Day," \ 6).

During his Nomination Acceptance Address, FDR relies heavily on building ties to historically relevant events while 
simultaneously arguing for a movement away from historical disasters. He claims the Democratic Party "by tradition and by the continuing logic of history, past and present, is the bearer of liberalism and progress" (1957, p. 647). Later, in his August $20^{\text {th }}$ response to Hoover's acceptance address, Roosevelt continues rooting his positions in historical contexts, albeit more recent history. He provides a "dispassionate review of the facts of history" (1938, p. 624) to discredit his opponent and the guiding tenets of the Republican Leadership (Note 3).

FDR's September 21, 1932 Portland Speech regarding public utilities and the development of hydroelectric power is also grounded in historical support. In it, Roosevelt cites a story of Lord Chancellor Hale and his justification for regulating ferryboat owners as the basis for modern philosophies regarding public utilities. He claims that as societies advanced governmental regulation of public utilities and other "necessities of a monopolistic character" became a widely accepted principle and "a basic part of our theory of Government long before the Declaration of Independence itself" (Roosevelt, 1938, p. 727).

Grounding his guiding principles in history enhances FDR's ethos and gives his arguments gravitas. FDR gives the impression of a statesman providing considered and historically weighty insights on important issues. In the Commonwealth Club Address, the use of history encourages careful deliberation of his perspective. So, in addition to supporting the educator persona, the "history lesson" enhances FDR's ethos by connecting to the recurring historical support developed throughout his campaign. The use of history, however, is not the only recurrent element across FDR's rhetoric.

A close analysis of several of Roosevelt's works reveals a consistent philosophy on government. Roosevelt views government as a malleable entity destined to evolve as societal contexts change. In the Commonwealth Club Address the argument for an adaptable government is clear. First, the "history lesson" illustrates the ways in which governments have been pliable over centuries of development in Europe and decades in the United States. Second, his specific examples of the need and ability for government to revise itself provide a foundation for his arguments regarding the necessity for government intervention in areas previously considered "private." FDR explains the impact of the Industrial Revolution on the role of government, stating, "Heretofore, government had merely been called upon to produce conditions within which people could live happily, labor peacefully, and rest secure. Now it was called upon to aid in the consummation of this new dream [an economic machine able to raise the standard of living for everyone]" (Roosevelt, 1932, II 18). This is the foundation for his argument favoring an evolution in the relationship between the government and the governed. After outlining the difficulties faced during the Depression and their causes, he argues,

Clearly, all this calls for a reappraisal of values...Our task now is not the discovery and exploitation of natural resources...It is the soberer, less dramatic business of administering resources...of seeking to reestablish foreign markets...of distributing wealth and products more equitably, of adapting existing economic organizations to service the people. The day of the enlightened administration has come. (II 26)

This basic assumption about the malleability of government and the need to enact a new, revolutionary approach to governing is essential to his proposed changes. It is also clearly present in many of the speeches leading up to the Commonwealth Club Address.

In his nomination acceptance address, Roosevelt points out the malleability of reified institutions and ideas. He explains, "We must lay hold of the fact that economic laws are not made by nature. They are made by human beings" ( 94 ). Understanding the human nature of such constructs allows for the possibility for humans to change them. This ability to alter government is also clear in FDR's Oglethorpe Commencement Address. By delineating ways in which governmental actions regarding regulation resulted in economic and social problems, Roosevelt demonstrates the real impact of governmental change and the possibility for positive alterations. This argument also occurs in his response to Hoover and the Portland Speech.

One of the most consistent elements of Roosevelt's governmental philosophy is his idea of the "individual." Unlike strictly singular interpretations of "individual," Roosevelt argues for government to take a "mass" approach to individuals. In many of his speeches and essays, FDR assumes the protection of individual rights to mean the rights of many individuals rather than the protection of a singular individual at the expense of the masses. In the 1925 "Jefferson" essay, Roosevelt wrote of the "scandal of the day" in the burgeoning America when the "moneyed class...made venerable fortunes from the stupidity or the need or the lack of inside information on the part of the thousands of veterans, tradesmen, farmers or frontier settlers" (Roosevelt, 1957, p. 45-6). The desire to protect the multitude of individuals from ill-motivated but powerful and ambitious individuals also appears in a discussion of labor relations during his October 20, 1928 speech while he campaigned for governor of New York (p. 56).

The famous Forgotten Man Address, given April 7, 1932, is filled with examples of Roosevelt's concern for the "mass individual." He talks of the "infantry of our economic army" and the "forgotten, the unorganized but the indispensable units of economic power" (Roosevelt, 1957, p. 66). Talking about groups of individuals in need of assistance, Roosevelt 
refocuses the discussion of economic evolution, emphasizing a populist approach to relief. Later, in the Oglethorpe Commencement Address, he points generally to the dangers of protecting the singular individual at the expense of the whole. He argues, "we cannot allow our economic life to be controlled by that small group of men whose chief outlook upon the social welfare is tinctured by the fact that they can make huge profits from the lending of money and the marketing of securities — an outlook which deserves the adjectives "selfish" and "opportunist"” (ף 9).

In his Nomination Acceptance Address, Roosevelt argues that protecting the "mass individual" is a traditional American goal. He declares, "Let us now and here highly resolve to resume the country's interrupted march along the path of real progress, of real justice, of real equality for all of our citizens, great and small" ( 9 ). Roosevelt delineates the connection between his idea of the role of government and the protection of the "mass individual" by contrasting "two ways of viewing the Government's duty in matters affecting economic and social life" (ब 13). He links the Republican approach to Toryism, explaining that it "sees to it that a favored few are helped and hopes some of their prosperity will leak through, sift through, to labor, to the farmer, to the small businessman" (II 13). FDR distinguishes his approach, arguing, "Ours must be a party of liberal thought, of planned action, of enlightened international outlook, and of the greatest good to the greatest number of our citizens" ( $\mathbb{\$} 15)$. He explains the foundation for his policy proposals as "based upon this simple moral principle: the welfare and the soundness of a Nation depend first upon what the great mass of the people wish and need; and second, whether or not they are getting it" ( $₫$ 52). He closes the address pledging a "new deal" and a call to "restore America to its own people" (\$ 63).

FDR's response to Hoover's nomination acceptance address contains the most explicit discussion of his conception of individualism. He explains,

I, too, believe in individualism; but I mean it in everything that the word implies. I believe that our industrial and economic system is made for individual men and women, and not individual men and women for the benefit of the system. I believe that the individual should have full liberty of action to make the most of himself: but I do not believe that in the name of that sacred word a few powerful interests should be permitted to make industrial cannon fodder of the lives of half of the population of the United States. (II 84-5)

He later continues, "...we must make the American individualism what it was intended to be-equality of opportunity for all, the right of exploitation for none" ( $(90)$.

Roosevelt echoes these ideas a few weeks later in his Portland Speech. He explains, "The liberty of the people to carry on their business should not be abridged unless the larger interests of the many are concerned. When the interests of the many are concerned, the interests of the few must yield. It is the purpose of the Government to see not only that the legitimate interests of the few are protected but that the welfare of the many are conserved" ( $\mid 5$ ). Roosevelt uses this position as grounds for arguing for government regulation of utilities, specifically, and two days later in the Commonwealth Club Address, he extends the argument to justify his new economic social contract.

The Commonwealth Club Address extends FDR's position regarding the mass approach to individual liberties and the government's role in protecting individual rights. He establishes his concern about allowing the ambition and ruthlessness of a few to go unchecked by repeatedly demonstrating the folly of such a perspective during the development of governments in Europe and the United States. He illustrates the general opposition to such unchecked powers by delineating responses to the abuse of power. Roosevelt explains, "The people sought a balancing — a limiting force...through town councils, trade guilds, national parliaments, by constitution and by popular participation and control, limitations on arbitrary power" ( $₫$ 12). Here he builds his argument for evolving the government while protecting the individual, collectively defined.

FDR contextualizes the concept of individualism against the backdrop of U. S. development in the "history lesson" of the Commonwealth Club Address. After explicating the Jefferson/Hamilton struggle, he expounds, "So began, in American life, the new day, the day of the individual against the system, the day in which individualism was made the great watchword of American life" ( 17 ). This "watchword," Roosevelt explains, is equivocal. He says some argue "individualism" means protecting the right of "personal competency" by removing government interests from economic concerns while others contend that protecting "individuals" necessitates the intrusion of government to secure and enforce such rights. Claiming that an evolutionary government should balance between the two, Roosevelt adopts the latter perspective. He asserts that the right of personal competency demands a new economic social contract requiring the government regulation of institutions "not to hamper individualism but to protect it" (ब 36). He explains, "should the group ever use its collective power contrary to the public welfare, the government must be swift to enter and protect the public interest" ( $₫ 39)$.

Related closely to his consistent conceptualization of individualism is Roosevelt's argument regarding what he considers the rights afforded to all. In the Commonwealth Club Address his argument for a new economic social order is predicated upon his interpretation of the Declaration of Independence. He delineates his assumptions thus: 
Every man has a right to life and this means that he has also a right to make a comfortable living...Every man has a right to his own property, which means a right to be assured, to the fullest extent attainable, in the safety of his savings... The final term of the high contract was for liberty and the pursuit of happiness...the right to read, to think, to speak, to choose and live a mode of life must be respected at all hazards. (II 35-41)

He summarizes the responsibility of government as "the maintenance of a balance, within which every individual may have a place if he will take it; in which every individual may find safety if he wishes it; in which every individual may attain such power as his ability permits, consistent with assuming the accompanying responsibility” (\$41).

Roosevelt's rights argument in the Commonwealth Club Address is consistent with his rights arguments in other addresses. In the Portland Speech he argues for an individual's right to reasonable access to necessary services. In his August response to Hoover, FDR expounds on the "sacredness of private property" and that "the individual should have full liberty of action to make the most of himself" ( $\$$ 86-7). Liberty of action and right to property are also present in his Nomination Acceptance Address when he speaks of the desires of the people, explaining, "To my mind they want two things: work, with all the moral and spiritual values that go with it; and with work, a reasonable measure of security—security for themselves and for their wives and children" (ब 53). Roosevelt is consistent in his arguments regarding the rights of citizens.

This brief examination of almost a decade of Roosevelt's speeches illustrates a the candidate's strong rhetorical consistency. Such constancy enhances FDR's perceived integrity by encouraging audience members to view him as predictable, trustworthy and reliable. In a time of economic turmoil and extreme uncertainty, Roosevelt positions himself as an unflappable and stable candidate. Roosevelt's rhetorical integrity is appealing in a tumultuous time.

\section{Discussion}

While the "greatness" of the Commonwealth Club Address is debatable, the value of the speech from a rhetorical standpoint is undeniable. Although many scholars focus on speeches of already elected candidates, closer examination of key campaign addresses by effective campaigners can reveal successful rhetorical strategies. As arguably the most successful presidential campaigner in U. S. history, Roosevelt's campaign addresses deserve close scrutiny. Although there are many to analyze, the Commonwealth Club Address stands with the Forgotten Man address and the Nomination Acceptance Address as the three key FDR campaign addresses presidential and rhetorical scholars acknowledge as influential and important (Lucas \& Medhurst, 2008). Of these speeches, the Commonwealth Club Address remains the least examined.

This analysis of Roosevelt's 1932 Commonwealth Club Address seeks to fill some of the "critical void" surrounding this famed speech by looking to the speech itself for clues regarding the effectiveness of the rhetorical strategies Roosevelt employs. By focusing on ethos enhancements FDR uses throughout the speech, it is clear that the address has more to offer than was suggested by Houck in 2004. The ingratiation attempts present in the introductory portion of the speech provide only one example of Roosevelt's rhetorical savvy when faced with a complex rhetorical situation. His adoption of complimentary personae throughout the speech helps propel his argument by borrowing from the credibility of educators and statesmen. Additionally, by staying true to the rhetorical and philosophical continuity established across many works spanning nearly a decade, Roosevelt creates a sense of stability and predictability for an audience facing a time of uncertainty. Certainly, FDR's Commonwealth Club Address provides a valuable lesson in ethos management for future campaigners and other orators.

\section{Acknowledgements}

Special thanks to Dr. Wil Linkugel for encouraging the continued exploration of Franklin Roosevelt's 1932 campaign orations and drawing the author's attention to this particular speech and Mr. Andrew Crick for his editorial assistance throughout the project.

\section{References}

American Rhetoric (n.d.). American Rhetoric: Top 100 Speeches. http://www.americanrhetoric.com/top100speechesall.html

Aristotle (1932). On Rhetoric (L. Cooper, Trans.). Englewood Cliffs, NJ: Prentice-Hall, Inc.

Boettinger, J. (1932). Gov. Roosevelt Gives Views on Big Business. Chicago Tribune, p. A1.

Burke, K. (1957). Philosophy of Literary Form. Berkeley, CA: University of California Press.

Burns, J. M. (2002). Roosevelt: The Lion and the Fox: 1, 1882-1940. Orlando, FL: Mariner Books.

Campbell, K. K., \& Burkholder, T. R. (1997). Critiques of Contemporary Rhetoric (2 ${ }^{\text {nd }}$ ed.). Belmont, CA: Wadsworth Publishing. 
Carey, C. (1996). Rhetorical Means of Persuasion. A.O. Rorty (Ed.), Essays on Aristotle's Rhetoric (pp. 51-84). Berkeley, CA: University of California Press.

Commonwealth Club of California (n.d.). About the Commonwealth Club. http://www.commonwealthclub.org

Denton Jr., R. E., \& Woodward, G. (1998). Political Communication in America. Westport, CT: Greenwood Publishing.

For Dynamic America. (1940). Time Magazine. http://www.time.com/time/magazine/article/0,9171,763219,00.html

Franklin D. Roosevelt: Commonwealth Club Address. (1932). The New York Times, p. A1.

Fried, A. (1999). FDR and His Enemies. New York: St. Martin's Press.

Gossnell, H. F. (1952). Champion Campaigner Frankiln D. Roosevelt. New York: Macmillan Press.

Gronbeck, B. (1975). Rhetorical history and rhetorical criticism: A distinction," Speech Teacher, $24,315$. http://blog.umd.edu/tpg/files/2012/08/Gronbeck-Speech-Teacher1.pdf

Horgan, C. (n.d.). America Between the Wars: New Deal; FDR's Ideology. http://www.gilderlehrman.org/teachers/html

Houck, D. W. (2004). FDR's Commonwealth Club Address: Redefining Individualism, Adjudicating Greatness. Rhetoric \& Public Affairs, 7, 259-282. http://dx.doi.org/10.1353/rap.2005.0006

Kuseski, B. K. (1995). Re-shaping the American Psychological Landscape: Franklin D. Roosevelt's 1932 Presidential Campaign. Unpublished doctoral dissertation, Northwestern University.

Leff, M. C., \& Mohrmann, G. P. (1995). Lincoln at Cooper Union: A Rhetorical Analysis of the Text. C. Burgchardt (Ed.), Readings in Rhetorical Criticism (p. 176-189). State College, PA: Strata Publishing.

Leuchtenburg, W. E. (2009). Franklin D. Roosevelt and the New Deal: 1932-1940. New York: Harper Perennial.

Linkugel, W. A. (1986). FDR: Master Campaigner. Paper presented at the meeting of the Central States Communication Association, Cincinnati, $\mathrm{OH}$.

Lu, X., \& Sullivan, R. (Eds.) (2004). Gems from the Top 100 Speeches: A Handy Source of Inspiration for Your Thoughts and Language. Shippenberg, PA: iUniverse.

Lucas S. E., \& Medhurst, M. J. (2008). Words of a Century: The Top 100 American Speeches, 1900-1999. New York: Oxford University Press, USA.

Milkis, S. (1985). Franklin D. Roosevelt and the Transcendence of Partisan Politics. Political Science Quarterly, 100, 479-504. http://www.jstor.org/stable/2151069

Parrish, M. W. (1995). The Study of Speeches. C. Burgchardt (Ed.), Readings in Rhetorical Criticism (pp. 35-46). State College, PA: Strata Publishing.

Ritchie, D. A. (2007). Electing FDR: The New Deal Campaign of 1932. Lawrence, KS: University Press of Kansas.

Roosevelt, F. D. (1932). Oglethorpe University Commencement Address. http://georgiainfo.usg.edu/FDRspeech32-1.htm

Roosevelt, F. D. (1932). Address at Jefferson Day Dinner in St. Paul, MN. Online by Gerhard Peters and John T. Woolley, The American Presidency Project. http://www.presidency.ucsb.edu/ws/?pid:88409

Roosevelt, F. D. (1932, September 23). Campaign Address on Progressive Government at the Commonwealth Club in San Francisco, California. Online by Gerhard Peters and John T. Woolley, The American Presidency Project. http://www.presidency.ucsb.edu/ws/?pid=88391

Roosevelt, F. D. (1938). Campaign Address at Columbus, Ohio. The Public Papers and Addresses of Franklin D. Roosevelt, 1, 623-624. New York: Random House.

Roosevelt, F. D. (1938). Nomination Acceptance Address. The Public Papers and Addresses of Franklin D. Roosevelt, 1, 647-659. New York: Random House.

Roosevelt, F. D. (1938). Portland Speech: Public Utilities Hydro-Electric Power. The Public Papers of Franklin D. Roosevelt, 1, 727-742. New York: Random House.

Roosevelt, F. D. (1957). Campaign Speech - Oct, 20, 1928, Buffalo, NY. B. Rauch (Ed.), Franklin D. Roosevelt: Selected Speeches, Messages, Press Conferences, and Letters. New York: Rinehart \& Co., Inc.

Roosevelt, F. D. (1957). Is there a Jefferson on the Horizon? B. Rauch (Ed.), Franklin D. Roosevelt: Selected Speeches, Messages, Press Conferences, and Letters, New York: Rinehart \& Co., Inc. 
Roosevelt, F. D. (1957). The "Forgotten Man" Radio Speech. B. Rauch (Ed.), Franklin D. Roosevelt: Selected Speeches, Messages, Press Conferences, and Letters. New York: Rinehart \& Co., Inc.

Rosenfield, L. W. (1995). The Anatomy of Critical Discourse. In C. Burgchardt (Ed.), Readings in Rhetorical Criticism, 68-87. State College, PA: Strata Publishing.

Vigil, T. R. (1999). Adapting to the Audience without Pulling Any Punches: FDR at the Commonwealth Club. Paper presented at the annual meeting of the National Communication Association, Chicago, IL.

\section{Notes}

Note 1. Aside from Houck's work, attention paid the speech by rhetorical scholars is limited to conference papers and mentions in doctoral dissertations. See, Brenda K. Kuseski, (1995); Wilmer A. Linkugel, (1986); and Tammy R. Vigil, (1999) for examples.

Note 2. In Political Communication in America, Denton and Woodward (1998) argue that the importance of such identification goes beyond voting by contributing to the creation and maintenance of social order.

Note 3. In his nomination acceptance FDR criticizes "Republican Leadership," stating he will not criticize the party at large. He is true to his word and, in another example of rhetorical consistency, focuses criticisms on "Republican Leadership" and particular individuals.

\section{(cc) EY}

This work is licensed under a Creative Commons Attribution 3.0 License. 